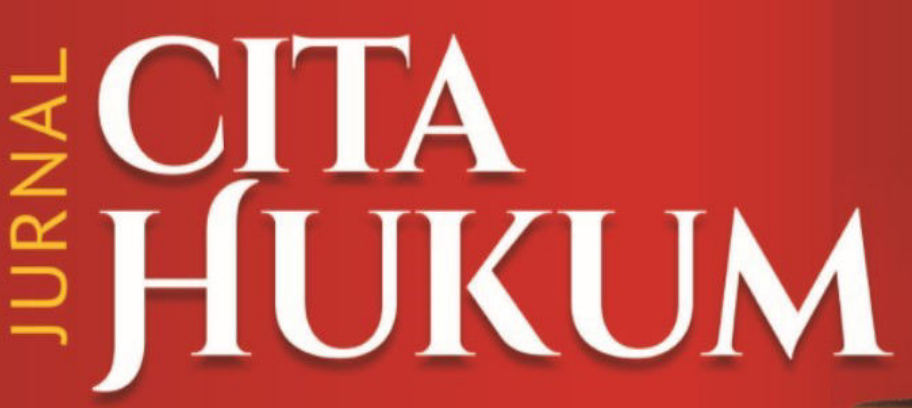

Indonesian Law Journal

- Analysis of the Nature of the Fulfillment of the Obligation in Iran and in France Civil Codes

Zahra Babajani, Saeid Kheradmandy \& Mohamad Javad Jafari. (Islamic Republic of Iran)

- Case Study of The Supreme Court Ruling Number: 3002 K/Pdt/2015 On The Validity of Provision of Income Agreement Which Was Made Before Divorce Based On Civil Code

Hazar Kusmayanti, Tri Utami Warapsari \& Linda Rachmainy. (Bandung, Indonesia)

- Malice in Crimes in Iran and The English Criminal Law

Peyman Rostamian, Mohammad Hossein Hajjarian, \& Hassan Ali Moazzanzadegan. (United Arab Emirates (UAE))

- Legislative Construction of the Post Amendment In Restoring Indonesian Democracy Asep Syarifuddin Hidayat. (Jakarta, Indonesia)

- The Implementation of Supreme Court Regulation Number 2 of 2012 concerning Limitation Adjustment of Mild Criminal Offenses and Amount of Fines in the Criminal Code Towards Handling of Minor Crime Cases

Abbas Sofwan Matlail Fajar \& Mara Sutan Rambe. (Islamic Republic of Pakistan)

- Legalizing Unofficial Marriage for Indonesian Migrant Workers In Malaysia

Afwan Faizin, Alfitra \& Ali Mansur. (Jakarta, Indonesia)

- Emancipation and Legal Justice; Portrait of Women's Legal Protection In Indonesia

Mentari Berliana Kemala Dewi \& Ridwan Arifin. (Semarang, Indonesia)

- The Role of Law on the Implementation of Green Banking in Indonesia Ria Safitri, Hartiwiningsih \& Hari Purwadi. (Surakarta, Indonesia)

- Роль спецслужб в ликвидации неповиновения (мятежных действий) в Индонезии и Филиппинах (Role of Secret Agent Institutions in Eradication of Rebels In Indonesia and Philippines)

Sekar Hapsari \& Saddam Aljihad. (Kazan, Federasi Russia) 


\section{VOLUME 7 NUMBER 1 (2019)}

JURNAL CITA HUKUM is Indonesian Law Journal published by Faculty of Sharia and Law, State Islamic University Syarif Hidayatullah Jakarta in Associate with Center for Study of Indonesian Constitution and Legislation (POSKO-LEGNAS) UIN Jakarta.

This journal specializes in Legal Studies and try to present various results of the latest and high-quality scientific research.

As an International Journal, all articles must be written in English or Russian, because they will be read online by millions of readers, both speakers of English and Russian.

JURNAL CITA HUKUM has been indexed at Web of Science (WOS) Web of Science (WOS) or Emerging Source Citation Index (ESCI) Clarivate Analytics, DOAJ, EBSCO, DIMENSION, Microsoft Academic Search, and SINTA 3 and become a CrossRef Member since year 2015. Therefore, all articles published by JURNAL CITA HUKUM will have unique DOI number.

\section{INTERNATIONAL EDITORIAL BOARD}

Prof. Carolyn Sappideen, Scopus ID: 6506771331 School of Law Western Sydney University, Australia

Prof. Alexander Fedorovich Malyy, Scopus Id: 57194874834 , Department of Constitutional Law, Kazan Federal University, Russian Federation

Prof. Razeen Sappideen, Scopus ID: 14041008300 School of Law Western Sydney University, Australia

Prof. Stanislav Shkel, Scopus Id: 56747984200, Department of Constitutional Law, Ufa State Petroleum Technological University, Russian Federation

Prof. Stefan Koos, Bundeswehr University Munich

Prof. Muhammad Munir, Scopus ID: 54414595100, Department of Law, International Islamic University Islamabad, Pakistan

Prof. Euis Nurlaelawati, Scopus ID: 56247081700, Faculty of Sharia and Law, State Islamic University (UIN) Sunan Kalijaga Yogyakarta

Prof Abdul Gani Abdullah, Universitas Islam Negeri Syarif Hidayatullah Jakarta

Prof. Salman Maggalatung, Center for the Study of Constitution and National Legislation (POSKOLEGNAS), Indonesia

Assoc. Prof. Asep Saepudin Jahar, Scopus ID: 57156653300 , Department of Economic Law Universitas Islam Negeri Syarif Hidayatullah Jakarta

Assoc. Prof. Ahmad Tholabi Kharlie, Thomson Reuters Id: R-5028-2017, Department of Family Law, Faculty of Sharia and Law, Universitas Islam Negeri Syarif Hidayatullah Jakarta

\section{EDITOR IN CHIEF}

Nur Rohim Yunus, Thomson Reuters Researcher ID: F-3477-2017, ORCID ID: 0000-0003-27821266, SSRN ID: 2645355, SINTA ID: 5975443, Department of Constitutional Law, UIN Syarif Hidayatullah Jakarta, Indonesia

\section{MANAGING EDITOR}

Muhammad Ishar Helmi, Thomson Reuters Researcher ID: F-3345-2017, ORCID ID: 0000-0001-7060-8191, SINTA ID: 6199804, Department of Criminal Law UIN Syarif Hidayatullah Jakarta, Indonesia.

\section{EDITORS}

Indra Rahmatullah, ORCID ID: 0000-0002-6160-4225, SINTA ID: 6200500, Department of Economic Law, Faculty of Sharia and Law, UIN Syarif Hidayatullah Jakarta, Indonesia

Fitria Fitria, ORCID ID: 0000-0001-9733-1233, Department of International Law, York Law School, University of York, UK, United Kingdom.

Mara Sutan Rambe, ORCID ID: 0000-0001-5404-6635, SINTA ID: 6200494, Department Criminal Law, Faculty of Law, UIN Syarif Hidayatullah Jakarta, Indonesia. Erwin Hikmatiar, Thomson Reuters Researcher ID: F-3235-2017, ORCID ID: 0000-0003-4103-818X, SINTA ID: 6200141, Center for The Study of Constitution and National Legislation (POSKOLEGNAS), UIN Jakarta.

Arip Purkon, ORCID ID: 0000-0002-6195-9384, Department of Law, University of Malaya, Malaysia.

\section{LANGUAGE EDITOR (ENGLISH AND RUSSIA)}

Raisa Shahrestani, Belgorodsky State University, Russia.

Firsty Izzata Bella, State Islamic University (UIN) Syarif Hidayatullah Jakarta, Indonesia.

\section{ASSISTANT TO THE EDITORS}

Anisaul Kamilah. State Islamic University (UIN) Syarif Hidayatullah Jakarta, Indonesia.

Firda Zahra, State Islamic University (UIN) Syarif Hidayatullah Jakarta, Indonesia.

Redaktur Office

Faculty of Sharia and Law UIN Syarif Hidayatullah Jakarta

Street Ir. H. Juanda 95 Ciputat Jakarta 15412

Phone. (62-21) 74711537, Faks. (62-21) 7491821

Website: www.fsh-uinjkt.net, E-mail: jurnal.citahukum@uinjkt.ac.id.

Link: http://journal.uinjkt.ac.id/index.php/citahukum 


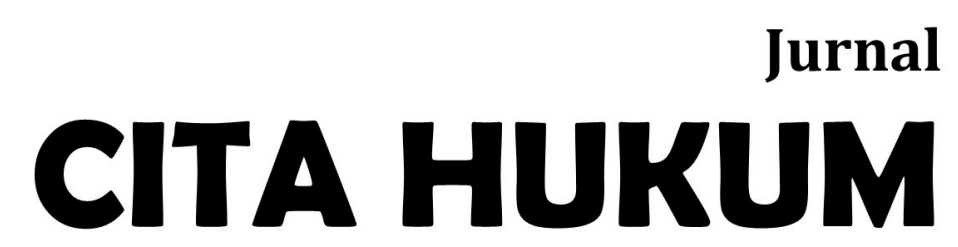

INDONESIAN LAW JOURNAL

Welcoming contributions from scientists, scholars, professionals, and researchers in the legal disciplines to be published and disseminated after going through script selection mechanisms, reviewing sustainable partners, and rigorous editing processes. 


\section{TABLE OF CONTENTS}

Analysis of the Nature of the Fulfillment of the Obligation in Iran

and in France Civil Codes

Zahra Babajani, Saeid Kheradmandy, Mohamad Javad Jafari

Case Study of The Supreme Court Ruling Number: 3002 K/Pdt/2015 On the Validity of Provision of Income Agreement Which Was Made Before Divorce Based on Civil Code Hazar Kusmayanti, Tri Utami Warapsari, Linda Rachmainy....

Malice in Crimes in Iran and The English Criminal Law

Peyman Rostamian, Mohammad Hossein Hajjarian, Hassan Ali Moazzanzadegan $.37-50$

Legislative Construction of the Post Amendment in Restoring Indonesian Democracy

Asep Syarifuddin Hidayat. $51-66$

The Implementation of Supreme Court Regulation Number 2 of 2012 concerning Limitation Adjustment of Mild Criminal Offenses and Amount of Fines in the Criminal Code Towards Handling of Minor Crime Cases

Abbas Sofwan Matlail Fajar, Mara Sutan Rambe. $.67-84$

Legalizing Unofficial Marriage for Indonesian Migrant Workers in Malaysia Afwan Faizin, Alfitra, Ali Mansur.

Emancipation and Legal Justice; Portrait of Women's Legal Protection in Indonesia Mentari Berliana Kemala Dewi, Ridwan Arifin.

The Role of Law on the Implementation of Green Banking in Indonesia

Ria Safitri, Hartiwiningsih, Hari Purwadi.... $115-138$

Роль Спецслужб В устранении Неповиновения или Мятежных Действий В Индонезии И Фидиппинах (Role of Secret Agent Institutions in Eradication of Rebels In Indonesia and Philippines)

Sekar Hapsari, Respiratori Saddam Aljihad. $.139-156$ 
JURNAL CITA HUKUM (Indonesian Law Journal)

FSH UIN Syarif Hidayatullah Jakarta

Vol. 7 No. 1 (2019), pp.51-66, DOI: 10.15408/jch.v7i1.10581

\title{
Legislative Construction of the Post Amendment In Restoring Indonesian Democracy*
}

\author{
Asep Syarifuddin Hidayat ${ }^{1}$ \\ Universitas Islam Negeri Syarif Hidayatullah Jakarta, Indonesia \\ do) $10.15408 /$ ich.v7i1.10581
}

\begin{abstract}
.
Restoring the face of Indonesian Democracy is complicated. Long phases in any case are needed until the real of Indonesian democracy is obtained. Constitutional amendments were also carried out to restore the meaning of democracy to achieve the benefits of democracy itself. As a result of the constitution being considered sacred and cannot be touched by the idea of change during the New Order, amendments became the only unavoidable alternative. The amendments were undergone in an effort to touch on the elements that are considered as the joint foundation of the establishment of democracy in this country. The things done in the amendments also relate to strengthening the contents of the institution which is the mandate of the constitution. Legislative construction is considered as the base of the joint which is the estuary of the concept of pure democracy. The addition of the DPD organs as a new institution in the Indonesian constitutional legislative structure is part of an effort to restore democracy in Indonesia. Therefore this construction effort has an impact on the opening of access to democracy so that it is no longer distant from the people, guaranteed individual and group freedom, upholding human rights, and opening the space for freedom for the press.
\end{abstract}

Keywords: Construction, Legislative Institution, Indonesian Democracy

How to cite (turabian):

Hidayat, Asep Syarifuddin. "Legislative Construction of the Post Amendment In Restoring Indonesian Democracy," Jurnal Cita Hukum [Online], Volume 7 Number 1 (20 March 2019).

2019.

* Received: Sept 17, 2018, revised: January 23, 2019, Accepted: February 25, 2019, Published: March 20,

${ }^{1}$ Asep Syarifuddin Hidayat is Senior Lecture at Law Department, UIN Syarif Hidayatullah Jakarta.

*Corresponding Author: asep.syarifuddin@uinjkt.ac.id. 


\title{
Abstrak
}

\section{Konstruksi Lembaga Legislatif Pasca Amandemen Dalam Merestorasi Demokrasi Indonesia}

Tema yang disandingkan dalam demokrasi yang pernah dilaksanakan di negara Indonesia adalah bentuk upaya para pemimpin untuk menemukan jati diri demokrasi yang sesuai dengan karakter bangsa serta dikehendaki oleh rakyat Indonesia. Berbagai langkah pun ditempuh untuk menemukan makna demokrasi sesungguhnya. Bahkan Amandemen pun dilakukan untuk mengembalikan makna demokrasi guna mencapai manfaat dari demokrasi itu sendiri sebagimana yang dikatakan para ahli hukum. Akibat konstitusi tidak dapat disentuh oleh ide perubahan, maka amandemen pun tidak dapat dihindari. Amandemen dilakukan dalam upaya menyentuh unsur-unsur yang dianggap sebagai pangkal sendi dari tegaknya demokrasi di Negara ini. Tidak hanya mengisi muatan kosong dalam konstitusi, hal lain yang dilakukan amandemen juga terkait penguatan isi lembaga yang merupakan amanat konstitusi. Konstruksi legislatif dianggap sebagai pangkal sendi yang menjadi muara konsep demokrasi murni. Penambahan organ DPD dalam struktur legislatif ketatanegaraan Indonesia menjadi salah satu usaha merestorasi demokrasi di Indonesia. Membuka akses demokrasi agar tidak berjarak dengan rakyat, menjamin kebebasan individu juga kelompok, menegakkan azasi manusia, memberi ruang untuk pers adalah beberapa materi yang dititipkan dalam mengfungsikan lembaga legislatif sebagai lembaga yang independen representasi rakyat. Lembaga lain dalam struktur legislatif yakni DPD yang lahir bersamaan amandemen ketiga UUD 1945 pada November tahun 2001, juga dibentuk dalam rangka pemenuhan demokrasi rasa keadilan bagi masyarakat di daerah yang tidak terjangkau secara geografis, juga keterbatasan akses terhadap perwakilannya.

Kata Kunci: Kontruksi, Lembaga Legislatif, Demokrasi Indonesia

\section{Законодательное построение пост-поправки в восстановлении индонезийской демократии}

\begin{abstract}
Аннотация.
В любом случае необходимы длинные фразы, пока не будет достигнута подлинная демократия Индонезии. Были также внесены конституционные поправки, чтобы восстановить значение демократии для достижения преимуществ самой демократии. В результате того, что конституция считается священной и не может быть затронута идеей изменений во время Нового порядка, поправки стали единственной неизбежной альтернативой. Поправки были внесены в попытке затронуть элементы, которые рассматриваются как совместный фундамент установления демократии в этой стране. То, что сделано в поправках, также касается укрепления содержания института, который является мандатом конституции. Законодательное строительство рассматривается как основа объединения, которое является устоявшимся понятием чистой демократии. Добавление органов DPD (региональное представительство) в качестве нового института в конституционную законодательную структуру Индонезии является частью усилий по восстановлению демократии в Индонезии. Поэтому эти усилия по строительству оказывают влияние на открытие доступа к демократии, так что она больше не находится на расстоянии от людей, гарантируется индивидуальная и групповая свобода, отстаиваются права человека и открываются возможности для прессы.
\end{abstract}

Ключевые Слова: строительство, законодательное учреждение, индонезийская демократия 


\section{Introduction}

The meaning of democracy is identically referring to the idea of Abraham Lincoln, which states "Government of the people, by the People, for The People." The notion implies that every citizen has rights in terms of the joint decision in the country since citizens also have rights over him, his life, and the absolute rights guaranteed in the constitution.

The application of democracy as stated by Abraham Lincoln is closely related to the overall system of state administration, which basically the implementation of an ideal state will impact on the welfare of its people. Absolutely, in terms of the application of democracy, the state needs to think about how ideal and proportionally the distribution of rights and the distribution of the obligations of the government and the implementation of the system in an effort to fulfill democracy, as Abraham Lincoln said, that is for people. Democracy as an instrument of government administration requires people's representation institutions as accommodation together in terms of taking attitudes and policies that are not only carried out by the government but also involve the people in the broadest sense (Asshiddiqie, 2012: 293).

The journey of democracy that has been carried out is a phase of the nation's history in an effort to find the identity of democracy "Indonesian's style" truly. Beginning with Parliamentary Democracy (1945-1949), Guided Democracy (1959-1965), Pancasila Democracy (1965-1998), until its peak in 1998 which led to reforms and amendments to the Indonesian's Constitutional of 1945, was a form of people's saturation of pseudo-democracy presented by organizers of this country (Yunus, 2015: 156-166).

The guarantee of democracy as stated in the constitution is contained in Article 28 I paragraph 1; "Everyone has the right to freedom of association, assembly and opinion" (UUD NRI 1945), gives meaning that everyone has the right to make an entity to speak up their aspirations or ideas as long as they are not in conflict with the ideology and constitution of the nation is a guarantee for pure democracy. The article became a tool to close the practice of theatrical democracy as had been done by state administrators before the reform.

In the period before the Reformation, the practice of engineering democracy carried out by the government was a quasi-policy in order to seek for personal or group benefits, and certainly ignored people's sovereignty. Even in the Pancasila democracies, it turns out that it does not escape the denial of democratic values which indirectly injure the noble values of Pancasila which are used as a tool to deceive democracy. 
Democracy as an instrument shows that general policy is determined on the basis of a majority by representatives who are effectively monitored by the people in periodic elections based on the principle of equality of politics held in an atmosphere of guaranteed political freedom (Azra, 2003: 110). The nuances of democracy as told by Azyumardi Azra, the professor at the Syarif Hidayatullah UIN, did not occur in the period before the Reformation. Moreover, the constitution is used as a tool to perpetuate power.

Authoritarian is the true feature behind the echoed democratic system. Hence, it can be understood that the legislature is also in an executive command, as well as intervention in a policy, as well as the reality of the duties and authorities of an institution that is no longer independent.

The theory says in the concept of a democratic state that the position of each state institution must be equally strong and control each other (cheeks and balances system), (Asshiddiqie, 2006: 154) this is essential to avoid the practice of rule by the man. Therefore, the party system has a healthy role in efforts to build democracy and create checks and balances systems in the operation of the constitutional system based on these principles.

French scholar Baron de Montesquieu developed the trias politica which was invented by Jhon Locke with the theory of separation and division of power which was made into the middle range theory to support the power of state institutions. He argued that the power consisted of three different but interrelated elements, those are the executives, the legislature, the judiciary (Asshiddiqie, 2006: 15). Montesquieu's view is currently used as the basis for the birth of the theory of separation of power.

Historically the birth of the theory is a form of rejection of the rule by the man government system, which then gave birth to the concept of state administration instrument with a new model of democracy which is actually the rule of law. The three institutions, namely the executive, legislative and judiciary have work correlation but the independence of the institution is separated through their respective powers, as is the theory of separation of power.

The concept of rule of law itself makes the legal mechanism a foundation or basis for carrying out obligations or accepting rights. For this reason, the constitution becomes the highest legal reference, following the hierarchy. In this regard, the legislature is certainly the only institution that is vital and full of interests, it can also be said to be a collection of personal or institutionalized and formal political struggles. This fact cannot be refuted, so strengthening the 
role of institutions through the development of patterns of cheeks and balances to become a system is a necessity to minimize the occurrence of corrupt systems as in the past that damaged the meaning of democracy. Another thing that is interesting in terms of building legislative construction in the implementation of democratic Pancasila values is the birth of the DPD institution as well as aligning the People's Consultative Assembly (MPR) with other high institutions and removing the position of the MPR as the highest state institution.

The plurality and nation's pluralism and integral geographical forms can be stated to be advantages, but also a weakness for Indonesian people. Groups that emerge as a form of disintegration are a threat to the integrity of the nation. According to this fact, the DPD was born through a third amendment, as a form of concern in the name of people's sovereignty.

\section{Democratic Restoration and Indonesian Values}

There are two reasons as a minimum that becomes the basis for studying the relationship between the State and society as an element of the State. In relation to the relationship between the two and the reciprocal linkages between the two, democracy is an instrument to regulate its proportionality. Firstly, almost all countries in the world have made democracy as a fundamental principle as it was published from the results of UNESCO study in the early 1950s which gathered more than 100 Western and Eastern scholars, while democratic countries have a role to the state and society to live in different portions (although they are equally democratic countries). Secondly, democracy as a state principle has essentially provided direction for the role of society to organize the State as the supreme organization, but it turns out that democracy runs on a different route (Mahfud, 2003: 18).

We understand that democracy is a form of government in which all citizens have equal rights in making decisions which are the consequence of submitting themselves to this country. Democracy allows citizens to contribute, either directly or through representatives. The scope of democracy is also very broad including social, economic and cultural conditions that allow the practice of political freedom freely and equally. Democracy is also a set of notions and principles about freedom along with their practices and procedures. Democracy implies the implementation of human dignity and values (Sumodiningrat \& Agustian, 2008: 44). For this reason, the principles of democracy become a benchmark for their success. As stated by Juan J. Lins and Alferd Stephan who formulated the basic criteria about Democracy that is, a legal freedom to formulate and support political alternatives with appropriate rights to freedom 
of association, speech and other basic freedoms for everyone, competition that free and anti-violence with periodic validity for them to hold government, all effective political positions are included in the democratic process and the right to participate in all members of the political community, whatever their political choices. Practically it is a freedom to establish political parties and the holding of free and honest elections for a certain period of time without removing any effective political office from the direct or indirect election accountability (Nurtjahyo, 2006: 72).

Another democracy principle is offered by Franz Magnis Suseno who said that the state can be said to be democratic after fulfilling the criteria: 1 ). State law; 2). The government which is controlled under the real community; 3 ). Free general election; 4). Majority principle; 5). There is a guarantee of democratic rights (Nurtjahyo, 2006: 74).

The above democracy principles are basic values which in essence synergize with the values of Pancasila as a national ideology. Even after 18 years of Indonesian reformation, the meaning of democracy seemed to make progress towards true democracy in this country. Freedom of expression, upholding human rights, law enforcement, accountable electoral processes, community involvement in policy making are realities in efforts to bring back the noble values of Indonesia as embodied in the Pancasila point.

Pancasila itself is an extract from the noble values which are crystallized into guidance points and way of life for the Indonesian nation, so that when compared there is no single thing that does not synergize with the principles of democracy, precisely by restoring democracy as this nation has returned value Indonesian values and national identity, namely Pancasila.

\section{Democratic Systems and Practices in Indonesia}

The development of democracy in Indonesia in terms of time can be divided into four periods, as:

\section{The period of 1945-1959 Parliamentary democracy.}

The era of parliamentary democracy in Indonesia often referred to as the era of constitutional democracy (Budiardjo, 2008: 128). The appearance of a parliamentary system in Indonesia due to the fall of the First Presidential Cabinet on $14^{\text {th }}$ November 1945 caused by the issuance of the Vice President's Declaration Number X/1945 on October 16, 1945 and followed later by a Government Declaration on November 3, 1945 which contained the call to 
establish political parties in Indonesia (Hanafie \& Suryani, 2011: 17). The existence of political, economic, and state security instability, made parliamentary democracy builds conflict within the scope of its own state administrators, a war of interests between the military and office generates group splits, even President Soekarno has the image of being a head of state as a "stamper" or "rubber stamp". Whereas on the other hand, the military demanded that they are included in resolving national issues because they felt that the military was born from the spirit of independence revolution that had the right to be involved in politics.

The culmination of political instability in the era of parliamentary democracy is the failure of members of the Constituent Assembly to form a new constitution for Indonesia. The Constituent Assembly's failure was caused by the Constituent members consisting of political parties in parliament never cooperating to reach consensus to form a new constitution. The Constituent's failure which eventually led President Soekarno to put forward what he called the "Presidential Conception" on February 21, 1957, in that conception Sukarno said that parliamentary democracy was a Western democracy and had to be replaced. The peak of political chaos at the time ended in the July 5, 1959 Presidential Decree stating that the Indonesian constitution returned to the Indonesian's Constitutional of 1945 which at the same time ended the last parliamentary cabinet headed by Ali Sastroamidjojo or what was called the Ali II Cabinet and the entire parliamentary democratic system in Indonesia (Budiardjo, 2008: 129).

\section{1959-1965 Period (Old Order) Guided Democracy}

After the end of parliamentary democracy era, Indonesia began to come into guided democracy. Guided democracy began when President Soekarno issued a Presidential Decree of July 5, 1959. Yet before the presidential decree was announced, parliamentary democracy or constitutional democracy still persisted with the formation of a transitional cabinet led by Ir. Djuanda or the so-called Djuanda Cabinet. This Djuanda Cabinet contains people outside the dominant party coalition in parliament, so the Djuanda Cabinet is often called the Extra-Parliamentary Cabinet. This cabinet began working from April 9, 1957, to July 10, 1959. (Hanafie \& Suryani, 2011: 47).

Long before guided democracy was formed, Soekarno definitely expressed his desire to change the Indonesian democratic system on January 27, 1957, in Bandung. Soekarno's idea, which began with expressing his desire to re-interfere government affairs even though the Constituent Assembly had not 
finished forming a new constitution yet. The continuation of his opinion, then Soekarno gathered the leaders of political parties to form an institution called the National Council (Hanafie \& Suryani, 2011: 48-49).

Guided democracy, initiated by President Soekarno, increasingly shows deviation and away from the concept and value of democracy itself, not only because of full intervention in the legislative and judicial institutions but also banning political parties that are considered against President Soekarno, such as Masjumi and the Indonesian Socialist Party (PSI) was dissolved and Soetan Sjahrir was then banished to Switzerland until his death in 1966, as well as the press and art institutions that were in conflict with President Soekarno or in conflict with PKI, such as the Pandji Masjarakat Daily and cultural activists who were members of Manikebu. In addition, President Soekarno prioritized foreign policy that was called the "Mercusuar Politics", this affected the neglect of national economic sector which caused great inflation and poverty.

The era of guided democracy ended with the darkest historical events for the Indonesian Nation, namely the events of the September 30 Movement/Indonesian Communist Party or G30S/PKI. The number of victims in the incident was not only 6 generals and 1 Indonesian Army officer, but also (allegedly) millions of communists who actually did not know anything about G30S/PKI were massacred in almost all parts of Indonesia. G30S/PKI in addition to ending the era of guided democracy, as well as initiating a new phase of dictatorship, the New Order's military dictatorship led by Soeharto or what is referred to as the Pancasila democracy era (Budiardjo, 2008: 130).

\section{Period 1965-1998 (New Order) Pancasila Democracy.}

Definition of Pancasila Democracy has several meanings as follows, Pancasila Democracy is a democracy based on family and mutual cooperation aimed for people's welfare, which contains elements of religious awareness, based on truth, noble love and noble character, Indonesian personality and continuity (Hatta, 1998: 87). In Pancasila democracy, the state organizing system is carried out by the people themselves or with the approval of the people (Nasution, 2010: 3. In Pancasila democracy individual freedom is not absolute, but must be harmonized with social responsibility (Latif, 2011: 383). In Pancasila democracy, the universality of the ideals of democracy is combined with the ideals of the life of Indonesian nation which is imbued with a spirit of family, so that there is no majority or minority domination (Latif, 2011: 250). 
In the Draft of the Republic of Indonesia's MPR TAP concerning Pancasila Democracy, it is stated that Pancasila Democracy is a norm that regulates the implementation of popular sovereignty and the administration of state government, in political, economic, socio-cultural and defense security, for every citizen of the Republic of Indonesia, social-political power organization, community organization, and other community institutions as well as state institutions both at the center and in the regions.

\section{1998-present period (Reformation).}

The process of political reform in Indonesia after the fall of President Soeharto in May 1998 has opened up opportunities for the growth of democratic values in order to create a good government. The Reform Process was divided into two phases, those are:

\section{First; Democratic Transition}

This phase of transition is actually the shortest, but most decisive phase because the failure of a country in the process of democratization depends on the process of democratic transition. The democratic transition or democratization process in Indonesia began when the transfer of authority from President Soeharto to Vice President BJ Habibie on May 21, 1998. It was called "transition" because at this phase Indonesia experienced a transition from an authoritarian political system to democracy, transition from military supremacy to civilian supremacy, the transition from centralization to decentralization, and so on, whose meaning that Indonesia has moved away from the dictatorial system and headed for change as a democratic country.

The collapse of the New Order has opened up a chance for political reform and the democratization process in Indonesia. The experience of the New Order has also made Indonesia realize that democracy is essential for the growth of people's welfare, therefore all Indonesian people post-1998 hopes that the democratization process under the leadership of President Habibie and the Development Reform Cabinet can run well and there will be no transition anomalies democracy such as from the Old Order to the New Order (Budiardjo, 2008: 134).

President Habibie who was sworn in to replace President Soeharto later became El Pilota del Cambio (means "The Pilot of Change - a nickname for King Juan Carlos who led political reform in post-Francisco Franco Spain), (Ajiputra, 2017: 62) bearing great responsibility to initiate democratization measures and put in place the main foundations for the democratic system in Indonesia, such 
as preparing democratic elections and making regulations, including also releasing New Order political prisoners. In the era of democratic transition, several new laws were formed, such as The Law of Political Parties, Election Laws, and also the Law of the People's Consultative Position Assembly as the Supreme State Institution also experienced changes (Budiardjo, 2008: 134).

The main concept of the democratic consolidation process according to Andreas Schedler is that when there is a country faces regime stability, it means that consolidation is determined by how stable the regime is, in this case how democratic consolidation is successful if the stability of a democratic regime can be maintained. According to Guillermo O'Donnell, if the consolidation of the regime has been achieved, then it is likely that the stability of the regime will also continue (Budiardjo, 2008: 335).

\section{Second; Legislative Institution Reconstruction through constitutional amendments}

The Indonesian's Constitutional of 1945 as a Ground Gezet is the highest reference for the implementation of the Indonesian constitutional system. Along with the development of an increasingly open and democratic nation, the amendments to the Indonesian's Constitutional of 1945 cannot be avoided, on the other hand, amendments were also made in an effort to make improvements to their material content.

According to Mahfud MD, based on a study of Indonesian's Constitutional of 1945, it was noted that there were some advantages in the contents which led to the non-implementation of democratic-constitutional government, including; (1) the absence of a check and balances system, (2) the number of attributes of authority, (3) there are multi-interpreted articles, (4) trusting of state administrators too much (Estede, 2018). The condition as stated by Mahfud MD is reinforced by open information to more critical and decisive people who want true democracy.

After an amendment to Indonesian's Constitutional of 1945, the Indonesian constitutional system experienced very crucial changes, such as changes to Article 2 Paragraph 1 of Indonesian's Constitutional of 1945: "The People's Consultative Assembly consists of members of People's Legislative Assembly, plus representatives from the regions and groups according to the rules stipulated by the Law." Become: "The People's Consultative Assembly consists of 1 member of the People's Legislative Assembly and the Regional Representative Council selected through general elections and further regulated by Law (UUD NRI 1945)." 
As in the results of amendments above, that is changes in Article 2 Paragraph 1 of Indonesian's Constitutional of 1945 was born a new institution in the Parliamentary system, namely the DPD (Regional Representative Council) which has an equal position with the DPR. Hence, it seems that the Indonesian government system tried to give birth to a new system of government in the form of a bicameral (system with two rooms) as it had been implemented in the UK consisting of the House of Lords and the House of Commons (Wicaksono, 2012: 97) and several other countries. The bicameral system itself is a forum that houses the two chambers of the institution in an official institution that performs a different task from the two institutions and will have other authority and functions for the position of the parliament when exercising its authority and function as the MPR.

Talking about other things from the position and function of DPR and DPD are both political institutions which philosophically have the duty as an official institution of policymakers in the draft law as stipulated in Indonesian's Constitutional of 1945 Article 20 and Article 22D. Slightly different from the DPR in its duties and authorities in Article 22D, the DPD has a function as a more specific institution in its proposed draft law relating to their respective regions as well as the implementation of autonomous regions. Another thing that is clearly visible in the implementation of the duties and authorities of the DPD is the function of assisting and completing the tasks of DPR in accommodating the interests of regional communities nationally in terms of making policies.

The following is a citation in Chapter VII A of Indonesian's Constitutional of 1945 concerning the Regional Representative Council that DPD's authority in Article 22 D:

"The Regional Representative Council can submit to the House of Representatives a draft law relating to regional autonomy, central and regional relations, formation and division and regional merger, management of natural resources and other economic resources, as well as those relating to central financial balance and area" (UUD NRI 1945)."

The above article can be understood that DPD has the enumerative authority only in the sense of helping to collect data related to the needs of each region represented by DPD which is then forwarded to the DPR, whereas in this case that DPD is a very strong institution because the constitution requires its existence, but for its duties and functions DPD is only complementary to assist DPR's main tasks. Seeing this, it is very unfortunate if the function of DPD is a constitutional mandate which is structured nationally but does not 
have the duties and functions as a vital existence for state institutions, although it may be very difficult to be released from the scope of work of DPR institutions.

Another thing as a weakness of DPD position and authority besides a limited authority is also related to the existence of several tasks and its power as if it only strengthens MPR institution which will be historically difficult to eliminate in the constitutional system. The limited authority of DPD is clearly very unbalanced with the other two institutions, both are DPR and MPR, but very limited existence is the composition of a very important institution in this country, the MPR.

Observing the limited position, authority and existence of DPD, these institutions are usually within the scope of regional government or at least synergize with DPRD which then has a system hierarchy up to the DPR. The limitation of members in each regional representative is also another thing which seems impossible to represent all the needs and demand of each region so that in order to maximize their duties and functions, the synergy of the DPD with regional institutions should be the key to the existence of DPD.

As stated in system theory by Craig Lundberg who defines a system that is a part of the whole system called a subsystem, and each system is a subsystem of a larger unit, from the subsystems described it is attempted to identify and formulate phenomena from various disciplines ( interdisciplinary) in the context of a frame of mind with general theory. The existing subsystem synergizes with each other so that the results of the system approach are The whole is more than the sum of its parts (Amirin, 2003: 1). The system theory proposed by Craig Lundberg can be identified as the position of DPD whose authority is in a subsystem that should work together in the same sub or equal level and build a larger system that is at the level of a high institution in the national system, in this case, is the DPR. In addition to limitate political interests, this can be done in an effort to realize checks and balances and minimize the authority attributes in the legislature as stated by Mahfud MD.

\section{The Reform of the Indonesian State Administration System After Amendment}

The state as the highest organization in an entity can be said as a legal entity because there is legal sovereignty in a country that binds the community and that must be obeyed by the community. As Hugo de Groot or Immanuel Kant stated, that the sovereign in the state is law. Therefore, awareness of the law 
and legal norms always limits state authority (Saleh, 2002: 35). For this reason, a country must have a constitution as a legal reference and even as a hierarchy of law, as the highest and fundamental source of law in a country. The constitution itself contains the consensus formulation regarding the goals and ideals of the nation, the building of state organs and procedures for regulating its power, relations either among state organs itself or with citizens (Asshiddiqie, 2014: 12).

The constitution is the pioneer of how a country carries out its duties. Therefore, the content of the constitution becomes a guideline and guidance for state institutions to play state duties. This clarifies the information regarding the reasons for amending Indonesian's Constitutional of 1945. Historical considerations are clearly a compelling reason to carry out amendments to Indonesian's Constitutional of 1945 which at that time the community was in severe disappointment with state administrators. The existence of a centralized authoritarian practice by state administrators using the constitution as a tool to perpetuate their power is clearly a bitter reality that changes the view of the sanctity of Indonesian's Constitutional of 1945 as a constitution.

Judging from Indonesia's history, the amendment to the constitution is a fact that accompanies the evolution of how the Indonesian nation built the ideal constitution and desired by power, the people. Since this nation proclaimed its independence various forms of effort have been made to find the ideal constitutional system and also the contents of the constitution.

The existence of the constitution is no longer regarded as something stagnant, rigid, and fixed. Legal political reforms even force changes in constitutional law and the constitution to become dynamic, more democratic and uphold humanity. For this reason, the constitution made adjustments to amendments and even increased space in human rights material.

October 19, 1999, was a historical milestone that broke the sacredness of Indonesian's Constitutional of 1945 because in the past it could not be touched by any change of idea. At that time, the first amendment was carried out and ratified at the general assembly of the MPR RI and continued until the annual session on 18 August 2000 The MPR RI set a second amendment. In contrast to the first amendment, in the second amendment, the scope of material for change is broader and more extensive, covering 27 detailed articles into 59 items (Asshiddiqie, 2014: 48). In this second amendment, in addition to expanding the content material, changes were also made to the addition of rooms to material content that did not previously exist, including the changes in the birth of DPD institutions. 
The Constitution of the Republic of Indonesia as a state constitution has passed four times of changes process. Along with the changes in the amendment process, so much of the Indonesian constitution experienced growth and development through its articles. The changes periodically occur in 1999 for the first time the Constitution was amended, then in 2000 the second change, the third change in 2001, and then 2002 for the fourth amendment. The change automatically moves the state institutional structure to change from before. These changes include, the return of democracy meaning which has only had a nominal value, for example in Article 1 of Indonesian's Constitutional of 1945 which states that the sovereignty of people represented by MPR as the highest state institution is returned by decreasing the position of MPR in line with high institutions other countries because sovereignty must be entirely in the will of the people. Other things, for instance, are also related to the authority of DPR and the Executive in terms of designing legislation, before the Executive Amendment is carried out as if it has a larger portion than the DPR but after the amendments, the work patterns and control of performance are more supervised.

Amendments were carried out as well as in order to perfect Indonesian's Constitutional of 1945 not only normatively but also nominally and semantically. Another reform that was built after the amendment was the pattern of working relations between institutions which according to the horizontal structure became a division of power, thus removing the pattern of monarchy that was built even though the state adhered to the principle of democracy. The state is controlled on the basis of popular sovereignty, not rule by the man. Whereas in the vertical structure, the work pattern that is built is the distribution of power, so that effectiveness and efficiency can be achieved without having to wait for the institution in the scope of the center to do it.

\section{DPD in The State System Structure and its Ideal Prospect}

The historical journey of DPD as a regional representative institution did not begin in 2000 in the second amendment. Far from that Indonesia has had regional representative institutions with various terms that have been used to interpret the institution.

The term of DPD at the outset was identified as a bicameral institution at the GAPI conference on 31 st January 1941, next the affairs of the Republic of Indonesia founding fathers and mothers region, then the history of regional envoys during the old order, the new order, and reform (Rosidi, 2015: 284). From the several versions, it is emphasized that the existence of regional 
representative institutions is not current in Indonesian constitutional system, but the phenomenon is that there is no institution capable of voicing regional interests. The birth of DPD as a constitutional mandate seemed to justify this assumption as if the regional government and the central government had a distance so that an institution was needed as a liaison between the two to convey regional interests.

\section{Conclusion}

From the discussion above, some conclusions can be drawn including:

Firstly, changes in the system and practice of democracy in Indonesia has occurred through four periods, starting from the period of parliamentary democracy, guided democracy, Pancasila democracy, and reform era democracy. These four phases have a significant impact ondemocracy development in Indonesia.

Secondly, democracy in the reform era has two phases of the developing democracy process, both are; the phase of transition to democracy under the control of the government of President B.J. Habibie and the phase of reconstruction of the legislature through constitutional amendments. These two phases are the way for institutional change and development in the government system of the Unitary State of the Republic of Indonesia.

Thirdly, there was a fundamental change in the constitutional amendments to Indonesian's Constitutional of 1945. The true sovereignty of the people was returned to people which had previously been carried out by the People's Consultative Assembly (MPR) as the highest state institution. As a result, the MPR Institution was positioned equally with other high-level institutions and placed Indonesian's Constitutional of 1945 in the highest position in the power hierarchy in Indonesia. In addition, Indonesian's Constitutional of 1945 received a special escort from an institution called the Constitutional Court as the Guardian of the Constitution.

Fourthly, with the change in the constitution after the amendment to Indonesian's Constitutional of 1945, the legislature in Indonesia has two rooms (bicameral), both are the DPR rooms and DPD rooms. However, members of both institutions are members of the People's Consultative Assembly.

\section{References:}

Ajiputra, G.S. Etnonasionalisme di Spanyol: Studi Tentang Konflik Separatisme Etnis Basque dan Catalan, Jakarta: FISIP UIN Jakarta, 2017. 
Aji, A.M.; Yunus, N.R. Basic Theory of Law and Justice, Jakarta: Jurisprudence Institute, 2018.

Amirin, T.M. Pokok-pokok Teori Sistem, Jakarta: PT. Raja Grafindo Persada, 2003.

Asshiddiqie, J. Hukum Tata Negara dan Pilar-Pilar Demokrasi Jakarta: Sinar Grafika, 2012.

Asshiddiqie, J. Konstitusi dan Konstitualisme Indonesia, Jakarta: Sinar Grafika, 2014.

Asshiddiqie, J. Pengantar Ilmu Hukum Tata Negara Jakarta: Sekretariat Jenderal Kepanitraan Mahkamah Konstitusi Republik Indonesia, 2006) Jilid II.

Azra, A. Demokrasi, Hak Asasi Manusia dan Masyarakat Madani. Jakarta: Tim ICCE UIN, 2003.

Budiardjo, M. Dasar-Dasar Ilmu Politik, Jakarta: Gramedia, 2008.

Hanafie, H; Suryani, Politik Indonesia, Jakarta: Lembaga Penelitian UIN Syarif Hidayatullah Jakarta, 2011.

Hatta, M. "Indonesia Merdeka" dalam karya lengkap Bung Hatta. Buku I: Kebangsaan dan Kerakyatan, Jakarta: Penerbit LP3ES,1998.

Latif, Y. Negara Paripurna. Historisitas, Rasionalitas dan Aktualitas Pancasila, Jakarta: Gramedia, 2011.

Maggalatung, A.S.; Aji, A.M.; Yunus, N.R. How The Law Works, Jakarta: Jurisprudence Institute, 2014.

MD, M.M. Demokrasi dan Konstitusi di Indonesia, Jakarta, PT. Rineka Cipta, 2003.

Nurtjahyo, H. Filsafat Demokrasi, PT. Bumi Aksara, Jakarta, 2006.

Pikiran dan Gagasan Adnan Buyung Nasution, Demokrasi Konstitusional, Jakarta: Kompas, 2010.

Rosidi, A. Kewenangan Dewan Perwakilan Daerah dalam Sistem Ketatanegaraan Republik Indonesia Berdasarkan Undang-undang Dasar Negara Republik Indonesia, (Jurnal Kajian Hukum dan Keadilan IUS, Vol. III/ Nomor. 8/ Agustus 2015.

Saleh, H. Civic Education, Jakarta: Audi Grafika, 2002.

Sumodiningrat, G; and Agustian, A.G. Mencintai Bangsa dan Negara Pegangan dalam Hidup Berbangsa dan Bernegara di Indonesia, Bogor: PT. Sarana Komunikasi Utama, 2008.

Wicaksono, D.A. Peran Mahkamah Konstitusi dalam Mewujudkan Fair Equality of Opportunity di Indonesia (Analisis Putusan Nomor 117/PUU-VII/2009, Jurnal Konstitusi: Kepaniteraan dan Sekretariat Jenderal Mahkamah Konstitusi Republik Indonesia, 2012.

Yunus, N.R. "Aktualisasi Demokrasi Pancasila Dalam Kehidupan Berbangsa dan Bernegara" dalam Jurnal Sosio Didaktika: Social Science Education Journal, Vol. 2 No. 2 (2015). 
in Collaboration with :

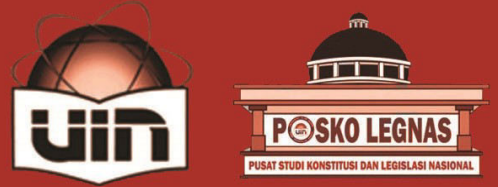

Indexed by :
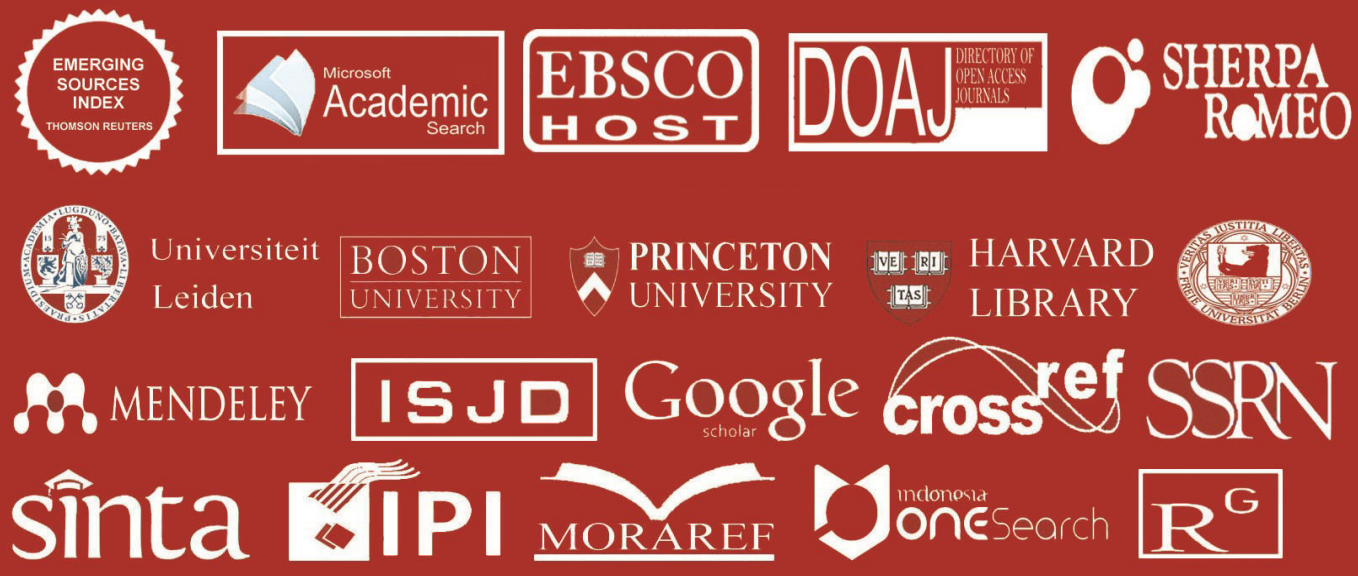

JURNAL CITA HUKUM is a peer-reviewed journal on Indonesian Law Studies published biannual (June \& December) by Faculty of Sharia and Law Universitas Islam Negeri Syarif Hidayatullah Jakarta in cooperation with Center for the Study of Constitution and National Legislation (POSKO-LEGNAS). JURNAL CITA HUKUM aims primarily to facilitate scholarly and professional discussions over current developments on legal issues in Indonesia as well as to publish innovative legal researches concerning Indonesian laws.
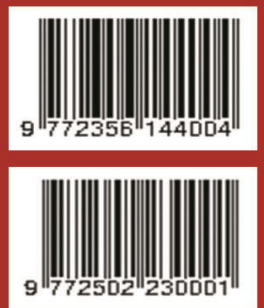